\title{
Surviving but not thriving: VOX and Spain in times of Covid-19
}

\author{
**Paper accepted for publication in Government \& Opposition**
}

Lisa Zanotti \& Stuart J. Turnbull-Dugarte

\section{Introduction}

On January $7^{\text {th }}, 2020$, the Spanish Socialist Worker's Party (PSOE) leader, Pedro Sánchez, was successfully (re-)confirmed as Spain's prime minister. Sánchez had been in power for six months already after gaining office via a vote of no confidence motion that was brought before the right-wing People's Party's (PP) leader, Mariano Rajoy in June 2018. After failing to gain enough parliamentary support in an initial general electoral contest in May 2019, Spanish voters were called to the polls for a second time in November. This second election provided the Socialists, with the support of Spain's far-left party, Unidas Podemos (UP), enough parliamentary seats to form a progressive left-wing coalition government.

Just as the Spanish Socialists' previous term in office (2004-2011) was dominated in large part by the arrival of the financial crisis and the subsequent Eurozone crisis, Spain's progressive coalition that gained executive office in January 2020 was faced with its own exogenous crisis in the form of the global pandemic caused by the outbreak of SARS-CoV-2 (coronavirus), commonly referred to as Covid-19. And just as Spain was one of the countries to suffer the most of the height of Europe's last (economic) crisis, it was, alongside Italy, one of the European status most negatively impacted by the world health crisis brought about by Covid-19, particularly during the early months of the pandemic (Dombey, 2020a; Minder, 2020).

As most other countries in Europe, Spain as of the time of writing has experienced three waves of Covid-19 contagion: the first in the spring 2020, the second during the fall of the same year and the third at the end of 2020 and first months of 2021. During the first wave, the government implemented a comprehensive, strict lockdown as well as other measures that 
restricted freedoms with the objective of limiting the contagion. After a subsequent relaxation of restrictions that took place after the first wave, and due to the country's high level of decentralization (Field, 2016), the decisions on subsequent restrictive measures were mostly taken at the regional level despite the national state of alarm remaining in force.

One notable distinction between the events of the financial and Eurozone crises, and those of Covid-19, is the presence of a new political player in the form of Spain's new populist

radical right party, VOX. But what has been the role of this new populist radical right party throughout the pandemic period? In our contribution to this special issue, we seek to advance the understanding of how the populist radical right in Spain reacted to Covid-19. While the first section describes the ideology of VOX and the reason behind its categorization as a populist radical right party, the rest of the article seeks to answer three questions. First, we consider how VOX discursively framed the pandemic. Second, we analyze how VOX as an opposition party, has responded to the pandemic through the analysis of the incentives, rationale, process, and consequences of the party's no confidence motion brought against the governing coalition in September 2020. Third, by analyzing the party's performance in the polls as well as support for VOX's leadership amongst the party's own voter base, we assess how the pandemic affected the popularity of the populist radical right.

\section{VOX: the populist radical right in Spain}

Until 2018, scholars referred to Spain as an 'exceptional case' in Western Europe due to the lack of populist radical right parties in the party system. Looking at both supply and demand side factors, Alonso and Rovira Kaltwasser (2015) pointed out that the absence of the populist radical right in Spain was largely the result of the former (p. 40). Things changed, however, in 2018 when a previously electorally irrelevant party (VOX) reached almost 11 percent of the vote in the Andalusian election. After gaining regional parliamentary representation in the 
south, VOX consolidated its position as central political force when in both the April and November general elections of 2019, it took home 10.26 and 15.09 percent of the vote, respectively, becoming the third largest party in the Spain's already fragmented multi-party system. Its national level success was also complemented via successive gains at the municipal, regional and supranational level. The details of VOX's rise from its early days in the political wilderness in 2013 to its significant regional-government supporting role across a number of Spain's autonomous regions has been detailed elsewhere (Rama et al., 2021). A significant degerming factor has been the ongoing dynamics of nationalist separatism in Catalonia 2017 (Turnbull-Dugarte, 2019) which has failed to be resolved by successive national governments, and an activation of salient anti-immigrant preferences among a vocal minority of the Spanish electorate (Mendes and Dennison, 2021; Rama et al, 2021).

\section{VOX as a populist radical right party}

Given the fact that VOX is a relatively new party - founded in 2013 as an ultra-conservative spin-off of PP defectors (Rama et al, 2021 - there is still some debate on how its ideological profile should be defined (Ferreira 2019). However, within the umbrella term of far-right parties (Mudde, 2019), we define VOX, in line with conceptualizations of the party elsewhere (Norris, 2020; Rooduijn et al., 2019), as a populist radical right-wing party. As XXX and XXX point out in the introduction of this special issue, parties that belong to the populist radical right share at least three ideological features: nativism, authoritarianism and populism (Mudde, 2007). First, nativism is an ideology that maintains that the nation state should be inhabited only by those considered "native" and exclude those individuals or ideas that threaten the imagined unity and homogeneity of the nation (Mudde 2007). It is worth noting that both the "natives" and the "aliens" are constructed categories. In general terms, after September 11, 2001 particularly because of the terrorist attacks perpetrated by the terrorist group Al-Qaeda - 
including terrorist events in Spain -, the 'aliens' became mainly Muslims (Betz and Meret, 2009). However, those categories vary also across countries depending on the specificities of the discourse of the populist radical right. ${ }^{\mathrm{i}}$

Discursively, at least in Europe, populist radical right-wing parties tend to express their nativism though anti-immigration stances. With respect to VOX, anti-immigration stances are present and are often combined with strong anti-globalism. The party's manifesto calls both for deportation of illegal immigrants and the application of new requirements for acquiring the Spanish citizenship based on language and cultural criteria (VOX 19: 5-6). Recent posts from the party's official Twitter profile (@vox_es) serve as prime examples of the party’s xenophobic nativism. In March 2021, for example, the party tweeted '[immigrants] storm our borders and violate our laws repeatedly with total impunity. They don't come to pay for a pension, they come to live off the Spanish people' and in a tweet two months earlier, the party commented 'that illegal immigration has multiplied the crime rate is not an opinion, it is a reality'.ii

Beyond the anti-immigration discourse, one of the peculiarities of VOX is that it expresses its ideological nativism also though a strong emphasis on defense of the national way of life, the exaltation of being Spanish, appealing to the pride of citizens, to patriotism (including a robust defense of Spain's blood-stained colonial past), and nationalism (Rama et al., 2021). This is extremely relevant in the case of Spain which is a high decentralized country divided into Autonomous Communities [Comunidades Autónomas]. Each one of these regions boast distinct cultural traits that, in most cases, overlap with the Spanish cultural tradition. While in most cases, dual identification is the norm, in some regions such as Catalonia or the Basque Country, a significative percentage of citizens identify only with the region (Pérez Nievas and Rama, 2018: 324-27). This goes against the allegedly homogeneity of the nation 
predicated by VOX. Indeed, it discursively contraposes the 'national values' to those 'particular forces' that allegedly aim at destroying the Spanish identity (Rama et al., 2021).

The second central ideological tenet of the populist radical right is authoritarianism, understood as the belief in a strictly ordered society. In general terms, these parties tend to translate this into policy preferences that advocate for stricter law-and-order measures. Typically, populist right-wing actors feel that threats to the natural order of things create insecurity which have 'to be dealt with an iron hand' (Mudde, 2019: 33). VOX is not an exception. Observations from the party's April 2019 manifesto demonstrate that authoritarian appeals to more law and order are one of the most salient, accounting for almost ten percent of the manifesto's space. Beyond security issues, VOX translates its ideological authoritarianism into a defense of traditional (Catholic-based) values, which contemplates for example the maintenance and stability of the traditional heteronormative family structure and the support for the role of religious institutions in state and society. Moreover, the discourse of VOX is characterized by a strong anti-feminist rhetoric (Bernardez-Rodal et al., 2020) and the party frequently claims that it's political offering in the party system is crucial in order to ensure the suppression of "subsidized radical feminist organization (VOX Manifesto: 17). In regard to this on the occasion of International Women's Day in 2020, VOX's representatives mentioned that 8 March celebrations are an "invention of the radical left", which allegedly depicts women as "victims" and "in opposition to men".iii

Finally, VOX is a populist party (Rama et al., 2021; Ribera Payá and Martínez, 2020; Turnbull-Dugarte et al., 2020). Populism is certainly less central than nativism and authoritarianism, but it still prominent for the party. As Riberá Paya and Díaz Martínez (2020) point out, the party "builds a populist narrative of Manichean conflict between the virtuous Spanish people/nation (which are one and the same), the evil globalist and progressive elites, surrounded by a myriad of threats to the Spanish nation". In this sense "the pure people" are 
defined as "patriots", while the "corrupt elite" are imagined as global (external) forces that aim at blurring and diluting Spain's national identity and autonomous sovereignty. An illustrative example of the populist rhetoric employed by the party can be found in the following tweet from January 2021, in which one of the party's MPs and VOX's spokesperson on defence, Agustín Rosety Fernández de Castro, stated:

'It is not a question of left or right; Is it globalism or patriotism. The globalists have a program designed by supranational organizations and large companies. We patriots believe that it is the sovereign nations who have to decide our future'. ${ }^{\text {iv }}$

\section{Made in China \& a threat to freedom: how VOX framed the pandemic}

Having established and defined VOX within the populist radical right-wing space, our first empirical starting point is to ask: how has VOX discursively framed the pandemic? Our argument, in brief, is that VOX articulated its response to the COVID-19 crisis in strong opposition towards the Socialist-led government, through the discursive expression of its ideological cornerstones. In other words, VOX, as a populist radical right party managed to discursively address the COVID-19 crisis by placing a strong emphasis on nativism and authoritarianism.

First, especially at the beginning of the crisis, VOX's leaders strongly criticized the performance of the government, arguing that it acted tardily to limit the spread of COVID-19 in the national territory. Prime Minister Pedro Sánchez declared the state of emergency on March $14^{\text {th }}$ which came almost two months after Italy's cabinet declared the state of emergency on January $31^{\text {st }}$. A clear example of VOX's attacks towards Sánchez' government was on the occasion of the March 8th demonstrations, which took place in Spain for International Women's Day, which the government allowed even though the situation of the pandemic was 
already problematic. As Wheeler points out, 'allowing the marches to go ahead as planned was clearly a mistake: banners held aloft among the estimated 120,000 protesters in Madrid with slogans including, "I would rather be killed by coronavirus than machismo" and "patriarchy is the worst virus" now seem naïve at best' (2020: 173). The March 8th demonstrations were central to VOX's accusation of government mishandling. In fact, VOX, alongside the People's Party, claimed that the demonstrations contributed to worsening the country's contagion. In a tweet, Rubén Pullido, the press secretary of VOX Andalucía, posted pictures of the demonstration on April 1 $1^{\text {st }}, 2020$ writing: 'today Spain passes 100,000 infections and goes towards 10,000 deaths, reckless!'. ${ }^{\mathrm{v}}$ Of course, it is also the case that VOX's decision to centre much of their critique of the government on the concrete events of the women's march seems, in part, an excuse to engage in anti-feminist messaging, which has become a commonplace tool in the party's authoritarian toolbox (Rama et al. 2021; Bernardez-Rodal et al., 2020).

The hypocritical nature of VOX's critique of the government's authorization for the $8^{\text {th }}$ March demonstration is apparent, however, given the party held its own annual convention on the very same day in a closed venue with more than 9000 supporters in attendance. It was also at this VOX convention that one of the party leaders, Javier Ortega Smith, showed signs of an illness and was diagnosed with COVID-19 only two days later. ${ }^{\text {vi }}$ In a now-deleted tweet, Ortega Smith boasted, much to the dismay of the Chinese Embassy in Madrid, that 'his Spanish antibodies were fighting against the damn Chinese virus'. ${ }^{\text {ii }}$ Demonizing Covid-19 as a Chinese export (very much a la Trump, see XXX in this special issue) as well as leaning into a romanticized image of belonging to the (superior) Spanish nation, is a classic example of VOX's rhetorical reliance on nationalist frames. The antagonistic presentation of Covid-19 as "made in China" is, however, not a line that the party has shied away from. Months after Ortega Smith's infection and huis China-bashing tweet, VOX's leader, Santiago Abascal, stated in a July 2020 speech in the national parliament that: 
'China is to blame. The Chinese communist government [...] is responsible for the pandemic, the Chinese communist government hides the data from the rest of the world, the Chinese communist government handles the World Health Organization (WHO) as it pleases. The WHO is an accomplice in this cover-up, and that is the reason why we [VOX] believe that Spain should leave the organization and redirect all the funds destined to this Chinese propaganda channel into research for developing a vaccine'. viii

With the country's epidemiological situation rapidly worsening, on March $25^{\text {th }}$ the Socialist-led government asked parliament to approve an extension to the state of emergency that was initially granted for fifteen days. On this sole occasion, VOX voted in favour of the extension but opposed all subsequent votes prolonging the lockdown measures that took place over the ongoing period of the pandemic. This attitude of non-compliance is linked to the party's strategy of emphasizing a preference for civil liberties and freedoms for the Spanish people, a least regarding the measures taken by the government to limit the spread of the virus. VOX presented scathing critiques on the lockdown measures and attacked all limitations on freedom of association and the closure of non-essential activities that the government imposed as a measure to limit spread of the virus.

As Wondreys and Mudde (2020) argue, VOX, as a populist radical right-wing party in opposition, has sought to discursively position itself as a defender of individual freedoms that are being curtailed by, what the party views, as an illegitimate ${ }^{\mathrm{ix}}$ government. VOX maintained that Spain's left-wing government used the state of emergency in a way it defined as 'abusive and dictatorial' often equating the government measures to those left-wing authoritarian regimes in Cuba, Venezuela or China. Critiquing the left-wing government as dictatorial, however, is not a feature of VOX's rhetoric that is unique to the pandemic. Throughout 2019 
and during the campaigns of the two general elections held that year, the party spoke frequently on the freedom-constraining 'progressive dictatorship' which it portrayed to be a constraint on the beliefs and preferences of the everyday Spaniard. ${ }^{\mathrm{x}}$ Such efforts reflect the Spanish farright's recent penchant for appropriating the rhetorical defense of "liberty" and the "dictatorial progressive left's" apparent desire to reduce it. This strategic framing of the left as being inimical to individual freedom was co-opted by the mainstream right and most explicitly demonstrated in the 2021 regional elections of Madrid where the People's Party candidate Isabel Díaz Ayuso - who aggressively campaigned on pro-liberty, anti-lockdown rhetoric in an attempt to put a stopper to neutralize VOX's ownership of the pro-freedom issue space using the slogan "comunismo o libertad" [communism or freedom] (Turnbull-Dugarte and Rama, 2021).

VOX's attack against the state of alarm measures also went beyond being a purely rhetorical device that could be used to lay assault on the government. At the end of April 2020, the party filed suit in Spain's Constitutional Court questioning the constitutionality of the state of alarm invoked by the PSOE-led coalition. According to VOX, the measures were adopted 'in clear violation of the rights and public freedoms of citizens. ${ }^{x i}$ In July of 2021, the Court partially upheld VOX's suit, declaring several provisions of the March $14^{\text {th }}$ royal decree unconstitutional and that the correct juridical instrument to tackle the pandemic was a "state of emergency" as opposed to a "state of alarm". xii

This appeal to libertarian values and a desire to protect freedom of movement from government restrictions goes hand in with the party's campaign strategy of seeking to appeal to voters beyond the bourgeoisie nationalists that form the core of their electoral base (Rama et al., 2021; Turnbull-Dugarte et al., 2020). On different occasions, VOX's leaders have maintained that the 'Spain that wakes up early' [la España que madruga], often particularly referring to the self-employed workers, like tradespeople (Rama et al., 2021), is the driving 
force that keeps the country going. VOX's defense of individuals' freedom of movement seems a strategy to attract the small business owners, independent contractors and self-employed from the negative economic consequences of the lockdown measures. If there is trade-off between health and wealth when it comes to managing Covid-19 (Hargreaves Heap et al., 2020), VOX's focus is clearly on the latter. We demonstrate this empirically in Figure 1 (panel a) by examining the party's position in comparison with the other national parties in Spain using data from the Chapel Hill Expert Survey (CHES). Vis-à-vis the party's contemporaries, including the centre-right People's Party, VOX is significantly more inclined to support more liberal restrictions that prioritize economic growth than more stringent restrictions that prioritize viral containment. 
a) Political party positions on Covid-19

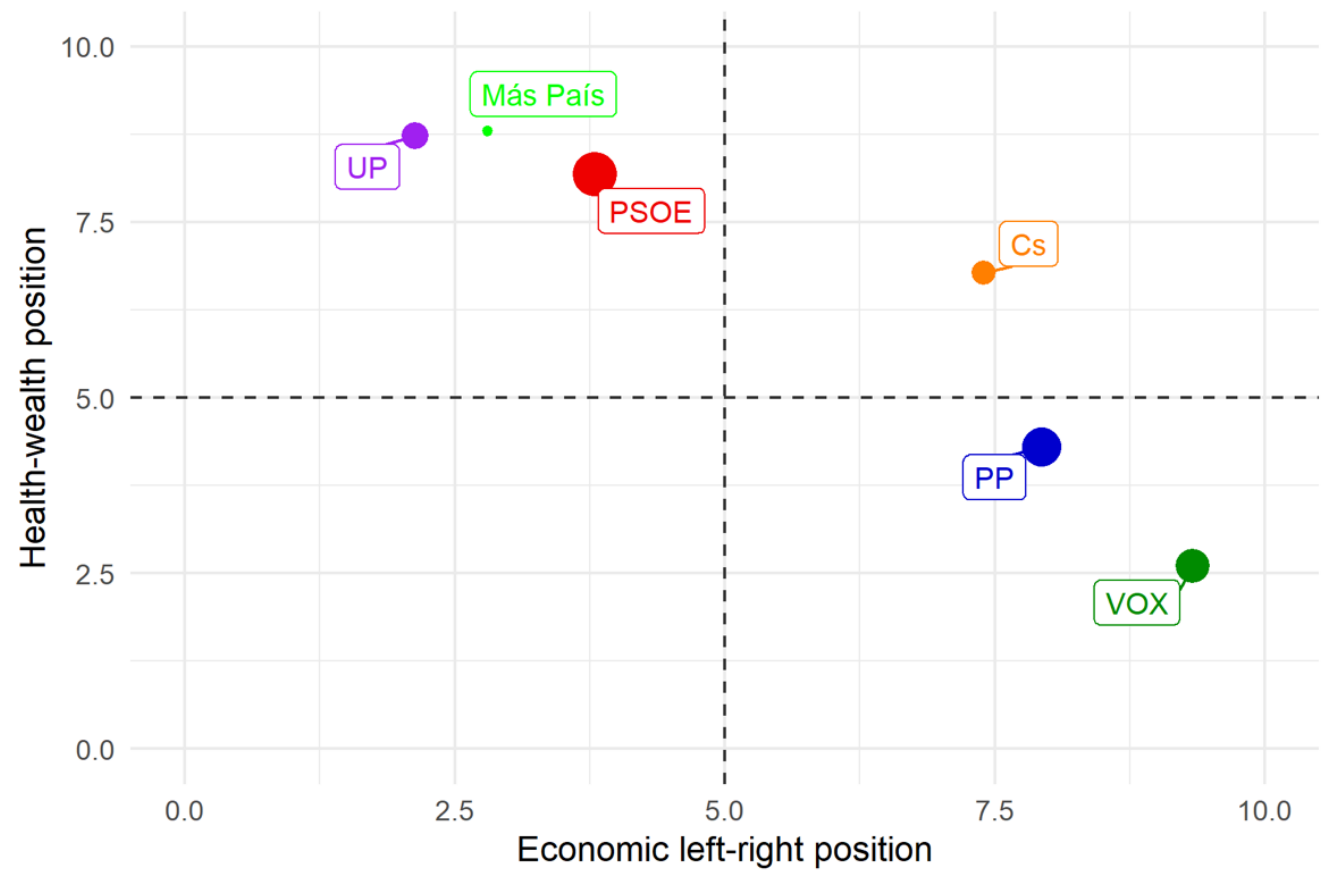

b) Party system polarisation on Covid-19

Figure 1: Spanish political parties, party system polarisation, \& Covid-19

Source: Elaboration of the authors based on CHES data 
Apart from their initial support for the state of the alarm at the very beginning of the state response to the pandemic in March 2020, VOX's attitude toward the pandemic and the government's management of the crisis has not changed. VOX has positioned itself as a consistent and strong critic of the left-wing governments' management of the pandemic as well the People's Party's compliance in permitting the continuation of the state of alarm (Olivas Osuna and Rama, 2021). In January 2021, for example, when asked about the need for a future lockdown, the party leader stated that '[a]nother lockdown would ruin us [Spain] and the PP would be complicit in helping it'. ${ }^{\text {xii }}$

Having a populist radical right party in opposition, whilst challenging the governing coalition, is also a thorn in the side of the mainstream right. In the war-like times that the arrival of Covid-19 instigated, the traditional confrontation between the established opposition and the governing parties, at least in the initial period of the crisis, softened with parties from the leftand right-leaning blocks that dominate the national legislature coming together to ensure that the necessary crisis-related response measures could be enacted. A move away from confrontational opposition behaviour is common in times of political crises (Chowanietz, 2011) and has been observed in other European legislatures at the beginning of the pandemic (Louwerse et al., 2021). The less confrontational strategy of Spain's centre-right opposition party, at least in the initial period of the pandemic (Dombey, 2020b), has provided VOX with an additional opportunity to fill the political void left vacant by a more consensual opposition in the form of the People's Party. As demonstrated in Figure 1, this is not to say that the People's Party has coalesced on Covid-19 preferences towards the PSOE's position. Indeed, there is still a wide ideological gap on Covid-19 responses between the two parties which is, undoubtedly, a contributing factor to Spain's position as the country in Europe with the highest level of system polarization ${ }^{\mathrm{xiv}}$ on Covid-19 measures (panel b). What is clear, however, is that 
the increasing crowded right-wing space allows VOX to attack the People's Party voter base whilst the People's Party is caught between a position of having to signal moderation in order to win the center ground whilst simultaneously trying to ward off a challenger on its right flank (Alonso and Field, 2021).

In the latter part of the pandemic, political discussion has moved increasingly further away from the issue of confinement and lockdowns and more towards Spain's vaccination plans. VOX's stance in relation to the Covid-19 vaccine has largely been twofold. First, the party has been quick to criticize the centralized vaccine purchase and redistribution scheme organized by the EU. Much like their typical claims regarding the sovereignty-limiting nature of EU membership (Turnbull-Dugarte and Devine, 2021), VOX argues that Spain's limited supply of vaccines at the start of programme was the result of the EU 'tying Spain's hands' and VOX actively advocated breaking away from the supranationally coordinated vaccine programme (Negrete, 2021). ${ }^{\mathrm{xv}}$

The second aspect of VOX's response, and very much in line with the rhetorical promise of protecting citizens against 'state oppression' promoted by Bolsonaro in Brazil (see $\mathrm{XXX}$, in this special issue), can be seen in the willingness of the party to provide a voice for vaccine sceptics. The data presented in Figures 2 and Figures 3 suggests that such a messaging strategy is likely to appease VOX voters. Just under one fifth of VOX's voters express skepticism of the necessity of lockdown measures and one third of their voters express an unwillingness to vaccinate themselves. The party's voters are host to the highest proportion of anti-vaxxers in comparison to the electoral supporters of all other parties, as well as those who don't engage in politics (abstainers). Interestingly, the highest level of reported willingness to vaccinate is not observed amongst either of the support bases of the two governing parties, but rather comes from those who voted for the People's Party, with 58\% of their voters expressing support for the vaccine. The rejection of vaccines amongst VOX's supporters marks them as 
very much distinct from the mainstream right. Given that the People's Party tends to source much of its electoral support from voters who are older, and those who are older are most at risk from the virus, the large level of support for the vaccine, relative to the voters of other parties, is not necessarily surprising. In a study on the determinants of vaccine anxiety, Jennings et al., (2021) show that both those individuals who distrust the government and are frequent social media users are less willing to take the Covid-19 vaccine. Both of these determinants are observed to be common amongst VOX's supporters (Turnbull-Dugarte et al., 2020).

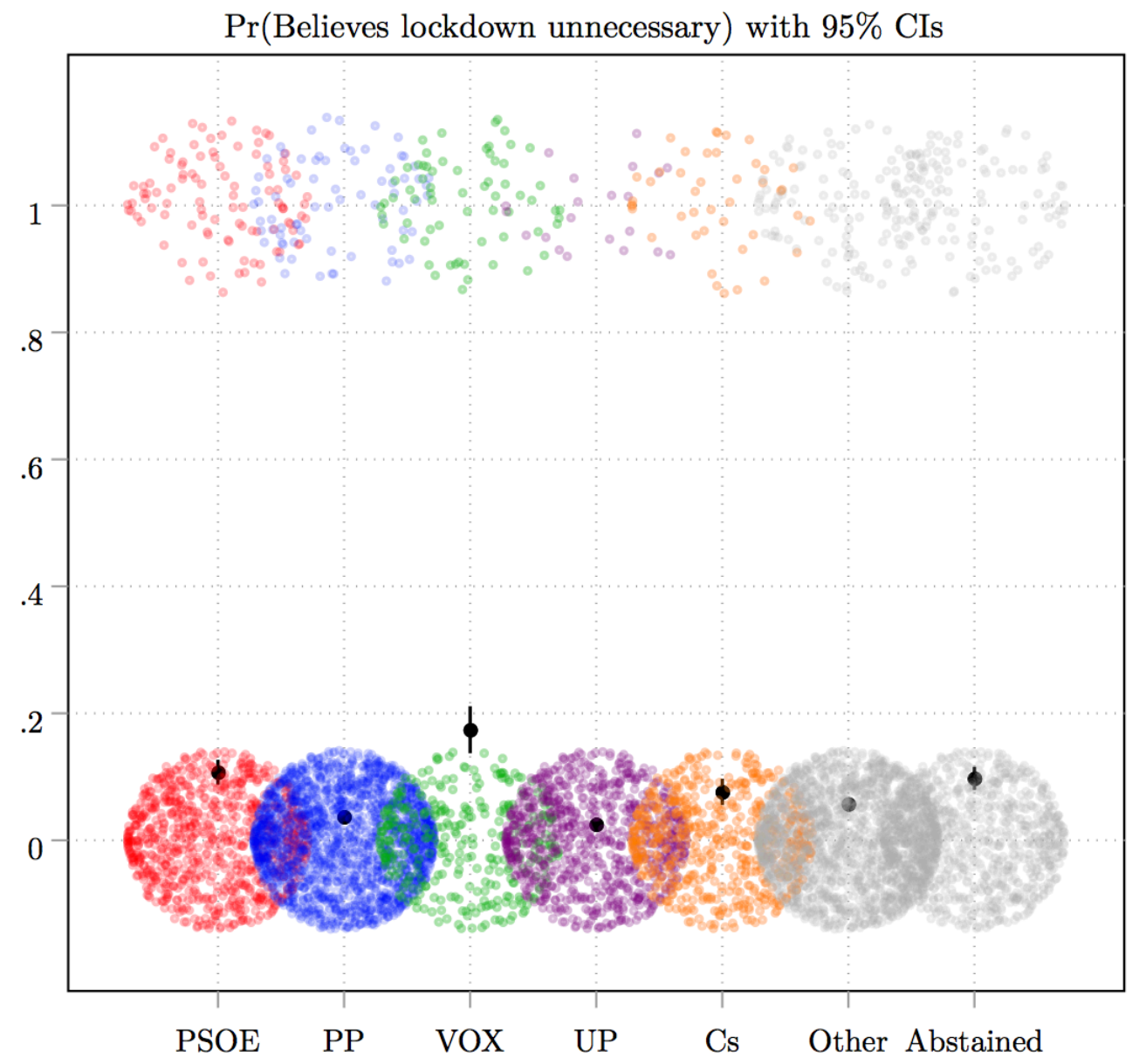

Figure 2: Partisan skepticism of Covid-19 lockdown (May-June 2020)

Source: Elaboration of the authors based on CIS monthly barometer data 


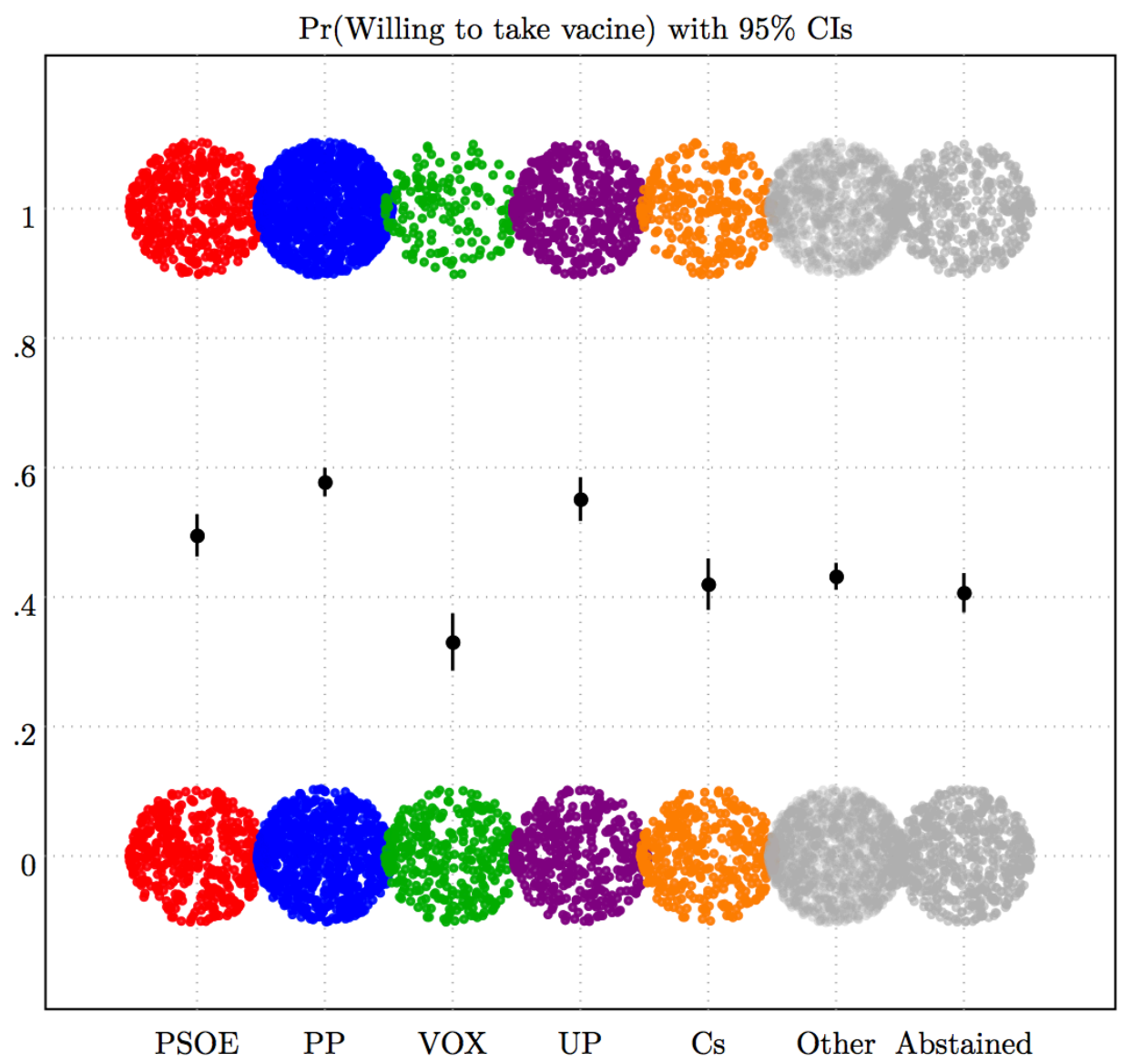

Figure 3: Partisan support for the Covid-19 vaccine

Source: Elaboration of the authors based on CIS monthly barometer data (Sep-Nov 2020)

\section{Seeking the limelight: how VOX responded to the pandemic}

In addition to adopting an aggressive rhetorical approach to challenging the government, Spain's populist radical right party also engaged in concrete actions that sought not only to attack the government and mainstream parties' handling of the pandemic, but also to ensure they were able to dominate the national media diet.

Seeking to rally public support for their criticism of the government and demands for the country to re-open, at the end of May VOX called for a convoy of car protests, bringing traffic to a standstill in many of Spain's major towns and cities. In Madrid alone, 15,000 protesters and 6,000 cars took part. With promises to remain in their vehicles as a means of 
following the social distancing rules - not always followed - VOX and their supporters sought to claim the moral high ground over the supposedly rabblerousing agitators behind International Women's Day (Wheeler 2020). VOX's spokesperson, Iván Espinosa de los Monteros, compared Madrid's protester-packed streets participating in the demonstration with the celebrations that took place when Spain won the 2010 Football World Cup. He claimed 'The closest thing to this I've ever seen was when we won the World Cup. People in the streets, civically and joyfully expressing their right to protest. ${ }^{\text {xvi }}$ In another example of the party seeking to rally their supporters, residents in Madrid protested in VOX-led demonstrations against the government for curtailing their freedoms over a period of weeks. Protesters manifested against the lockdown through cacerolazos (pot drumming) and crying out 'freedom'. These protests were largely clustered around Madrid's most affluent neighbourhood, Salamanca, which, as Rama et al (2021) show, is one of the areas with the highest localized concentration of far-right supporters in the country.

The most explicit example of VOX's active leadership in attacks against the government, in addition to protest activities mentioned above, came in the form of legislative motions. During a congressional plenary session on the $29^{\text {th }}$ of July 2020, VOX's party leader announced that the party would bring forward a government-censuring vote of no confidence against the Sánchez-led coalition. No-confidence votes, at least at the national level are a rarity in Spanish politics. One explanation for this is that the rules of the Spanish Constitution require that any government censure must be constructive: Article 113 of the Constitution stipulates that the removal of the current government does not lead to the dissolution of the chamber and the calling of elections, but rather must coincide with the installation of a new alternative government. In essence, votes of no confidence must seek an absolute majority of the chamber to remove the sitting government and simultaneously install another with a named candidate as the alternate president. Since Spain's transition to democracy, and prior to VOX's motion 
against the Sánchez government, there have only ever been four no confidence votes tabled in the Spanish Congress. Two of these were brought against Spain's former Prime Minister, the People's Party's Mariano Rajoy, the second of which was the first example of a no confidence vote gathering the necessary support to actually remove a national government from power (Simón, 2020).

VOX's motion, announced on July $29^{\text {th }}$, was tabled on September $29^{\text {th }}$ when the party's parliamentary group presented a 34-page document laying out their accusations against the government. The accusations of the motion were four: (i) the 'fraudulent' constitution of the 'social communist' government and its reliance of separatist forces, (ii) the 'criminal management' of the coronavirus pandemic, (iii) the 'democratic degeneration' and 'assault' on institutional controls on executive power, and (iv) the 'unconstitutional restriction' of the individual liberties of the Spanish people. Three of the four (ii-iv) allegations were concerned with coronavirus and echoes the party's electorally strategic representation of liberty as being under threat from the left-leaning "socio-communist" government.

Table 1: Partisan composition of 14 th legislature $\&$ vote in no confidence motion

\begin{tabular}{lcc}
\hline Party & Seats & $\begin{array}{c}\text { Vote in no confidence motion } \\
\text { tabled by VOX }\end{array}$ \\
\hline $\begin{array}{l}\text { Left-wing parties } \\
\text { PSOE }\end{array}$ & $120^{*}$ & No \\
Unidas Podemos & $35^{*}$ & No \\
Right-wing parties & & No \\
People's Party & 89 & Yes \\
VOX & 52 & No \\
Ciudadanos & 10 & \\
Regional nationalist parties & & No \\
ERC & $13^{\dagger}$ & No \\
JxCat & 8 & No \\
PNV & $6^{*}$ & No \\
EH Bildu & $5^{\dagger}$ & No \\
CUP & 2 & No \\
Coalición Canaria - Nueva Canarias & $2^{*}$ & No \\
Navarra Suma & 2 & No \\
BNG & $1^{*}$ &
\end{tabular}


Other parties

Más País

$3^{*}$

Teruel Existe

Total MPs

350

No

No

*Parties that voted to confirm Sánchez as president in January 2020

†Parties that abstained in Sánchez investiture vote

$\$$ Coalición Canaria - Nueva Canarias split with one vote in favour and one against Sánchez investiture

Bringing forth the no confidence motion that named VOX's own leasder, Santiago Abascal, as the presidential candidate had little chance of gathering an absolute majority in Congress. As demonstrated in Table 1, the parliamentary arithmetic was not stacked in VOX's favour, since for the motion to pass successfully the party would need to find a way to break the 176-MP majority that installed the Sánchez-led government in January 2020 just before the pandemic struck Spain. In the period between the tabling of the motion and the parliamentary vote, VOX found very little legislative support and no parliamentary party provided an endorsement for VOX's motion. In fact, parliamentarians on both the left and right were quick to highlight the clear motivations of political theatre behind the legislative manoeuvre. Citizens [Ciudadanos], Spain's centre-right and self-described liberal party, despite enjoying a juniorcoalition partner role in several regional and municipal governments that are propped up by VOX's legislative support, was quick to condemn the motion, calling it 'partisan, inappropriate, and irresponsible.' The People's Party's general secretary, Teodoro García Egea, also signaled his disapproval of the motion tabled by VOX, commenting in a tweet - 'The People's Party will always be focused on what matters: saving lives and jobs. They can't count on us to support a political distraction that will only strengthen the PSOE. ${ }^{\text {xvii }}$

Right up until the day of the no confidence debates (October $21^{\text {st }}-22^{\text {nd }}$ ), what remained unclear, however, was how Pablo Casado - the People's Party leader-would vote on the motion. In advance of the motion's debate Casado made no public statements regarding the 
issue and People's Party parliamentarians commented to journalists that they hadn't been told where the party whip would fall. When Casado spoke during the debate, he launched an unexpected and aggressive counterattack against the populist challenger, making explicit that if VOX brought forward the motion to 'supplant' his party, then they should give up all hope. The explicitly scathing attack on VOX - a party that propped up PP-led coalitions and minority governments in different localities took VOX and political commentators by surprise. Casado strategically monopolized his debate time to ridicule and delegitimize VOX, highlighting, for example, that whilst VOX was rallying its supporters to follow the party leader in an open-top bus during the height of the pandemic, the People's Party was working with the government to implement policy responses (Casado, 2020). Casado also went to great lengths to communicate the divergences between the People's Party and VOX, reiterating, somewhat satirically, the anti-globalist, anti-European and pro-Trumpian messages that had dominated much of Abascal's parliamentary intervention. There were even some personal attacks against Abascal when Casado accused VOX's leader of being a political opportunist, who was seeking to attack the party that had advanced his political career for the last 15 years (Casado, 2020) - a reference to Abascal's former political career within the People's Party himself. The resulting defeat of the motion was widely considered an embarrassing failure for the far right and for Abascal personally.

Despite the motion's slim chances of success and ultimate failure once the People's Party's opposition became clear, the process provided VOX with unprecedented media exposure. Spain's congressional regulations provide the proposed alternate candidate with unlimited time to make their case against the government. Bringing forth the motion can, therefore, be seen as an act of political theatre; one that allowed VOX and Abascal to gain unprecedented media access via the motion's domination of the legislative agenda and the media narrative that would accompany it. Media exposure for populist radical right-wing 
parties matters. As a wide body of literature highlights, the level of support for these parties is often enhanced by greater levels of media attention (Devine and Murphy, 2020). By guaranteeing that its leader would be at the front and center of political reporting, VOX was able to make certain its populist messaging was transmitted on prime time whilst also ensuring that, for their prospective voters of the right, VOX was perceived as the dominant and active party of the opposition.

Bringing the no confidence vote against the Socialist-led coalition was just as much an attack on the mainstream People's Party 's hegemonic position as the leader of the Spanish right as it was an assault against the left-wing block in power. VOX, as a political challenger with yet no direct governing experience, is able to attack the establishment parties, including the People's Party without having to assume the responsibility of government participation (Alsono and Field, 2021). As demonstrated by DeVries and Hobolt (2020), being free of governing experience can provide political challengers with a strategic advantage when it comes to attacking mainstream party dominance, and this is a strategic stance that VOX has sought to leverage to their advantage.

\section{Support for VOX among the electorate: victims or victor of the pandemic?}

When the spread of Covid-19 across Europe began to become clear, many political pundits were quick to point towards the potential negative effects of Covid-19 for the survival of populist radical right parties. The arrival of the pandemic resulted in many op-eds (see, for example; English, 2020; Rachman, 2020) highlighting Covid-19's silver-lining in aiding the downfall of the populist radical right. In seeking to assess the electoral consequences of the pandemic for the populist radical right, we demonstrate that such prophesizing has failed to come to fruition in the case of Spain. 
Figure 4 shows the polling averages enjoyed by each of Spain's top five national parties: the Socialists (PSOE), their far-left junior coalition partners (Unidas Podemos), the right-wing People's Party (PP), the self-penned liberal party, Citizens (Cs) and VOX. One of the most striking conclusions illustrated in polling data is the strong polling performance enjoyed by the government-leading Socialist party. Between the official election results of November 2019 until March 2021, there has been no shift of substance or significance in the public's voting intentions for the Socialists. This is at odds with evidence of 'rally around the flag' effects observed elsewhere (Baekgaard et al., 2020; Bol et al., 2021), which tend to show support for governing parties increasing during the pandemic, particularly around earlier periods around the time of lockdown announcements (Bol et al., 2021). The main governing party's resilience in the polls, at least up until late spring 2021, contrasts starkly with the electoral punishment endured by the US' populist radical right-wing president, Donald Trump, (see XXX, in this special issue), whose (mis)management of the pandemic has been signaled as a significant determinant in explaining his electoral defeat in November 2020 (Neundorf and Pardos-Prado, 2020). 


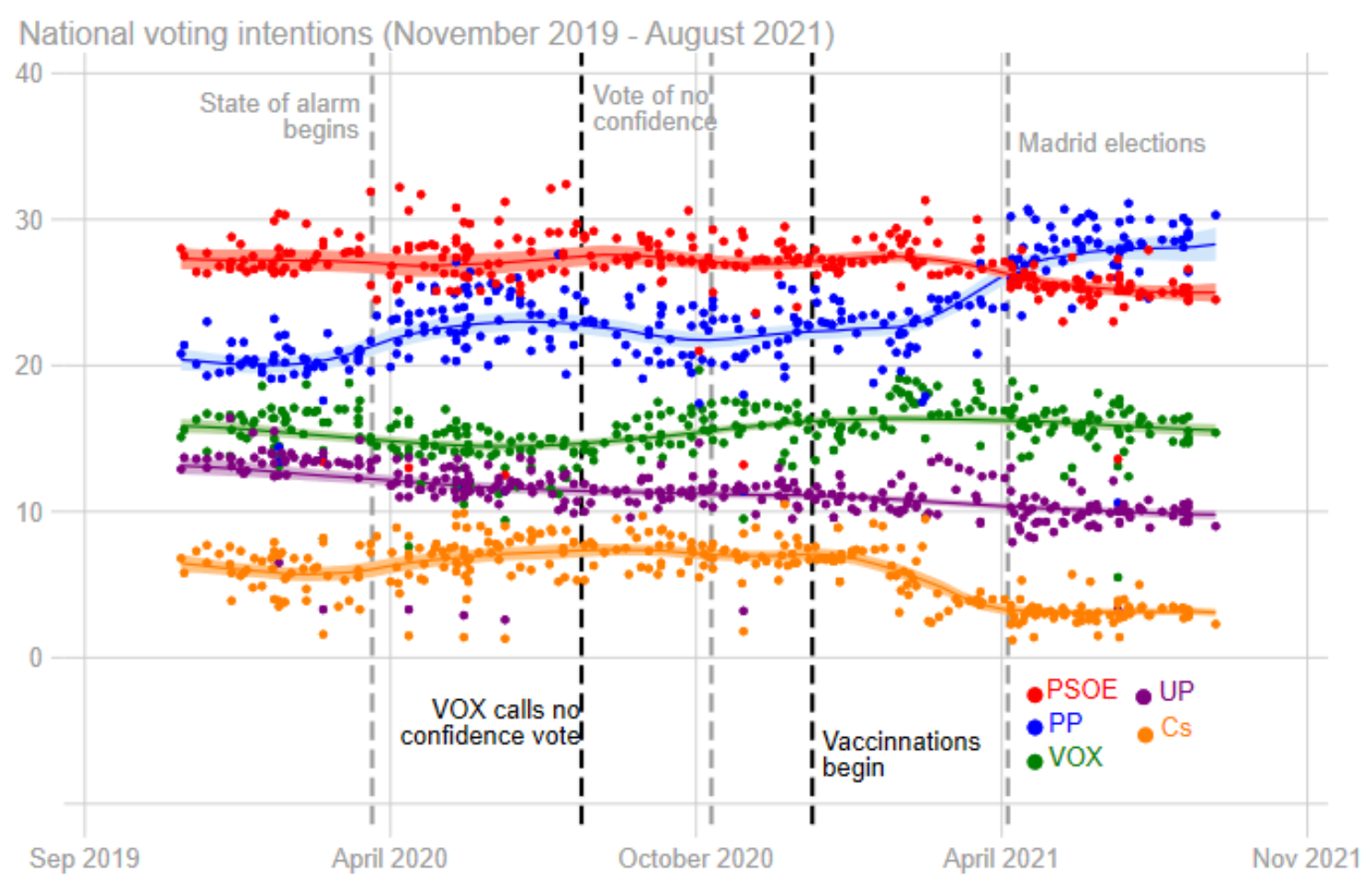

Figure 4: Party polling averages (November 2019 - January 2021)

Source: Elaboration of the authors based on available polling data

When it comes to assessing support for the populist radical right in Spain, what is clear is that there were, if however short-term, changes in the public's declared voting intentions for this party family. During the period of late March 2020 when the first national lockdown was announced, there was a significant fall in the level of support for VOX. Of note, is that this drop in citizens' voting intentions for VOX coincided with an increase in voting intentions for the PP. Whilst Spain's governing parties may not have been able to harvest the benefits of any rally around the flag effect, the same is not true for the mainstream right, with citizens on the right appearing to move their support towards the more established, and governmentexperienced, People's Party. 
One of the factors that can aid us to understand VOX's (small) downward slump in the polls in the time immediately after national lockdown was announced is the party's entrepreneurial status as a political outsider. Exogenous crises tend to induce electoral penalties for political challengers, particularly in the short-term (Delis et al., 2020). Voters are assumed to be risk-averse when faced with crisis situations and, consequently, are often demonstrated to place a political premium on governing experience rather than entrepreneurial status (Morgenstern and Zechmeister, 2001). This occurs because citizens move to counteract systemic uncertainty and political or economic insecurity by opting for political alternatives that represent stability and continuity, rather than supporting anti-establishment parties that may 'further fuel the fire' presented by these exogenous shocks (Delis et al., 2020). Applying this to the case of Covid-19 and the Spanish government's state of alarm declaration, a convergence of support around the mainstream right at the cost of the populist radical right would be consistent with historical evidence from other crises responses in Spain (Delis et al., 2020).

Nevertheless, the downward trends in VOX's support at the height of the first lockdown were short-lived. As illustrated in Figure 4, Abascal's announcement of a censure motion against the Socialist and far-left (UP) 'criminal dictatorship' government led to a return to the same polling position enjoyed by the party before the announcement of the stringent Covid-19 lockdown measures. As discussed above, this legislative maneuver was strategically implemented in the hope of surpassing the PP's polling numbers amongst right-wing voters and to ensure VOX took centre stage in the media discussion of parliamentary events. Whilst the party's attempts to politically outmaneuver a lackluster People's Party opposition might not have resulted in their rise as the primary right-wing party, it did serve to revoke any potential electoral advantage that the mainstream right had previously been able to enjoy since the beginning of the lockdown in March 2020. VOX's polling numbers in early 2021, in a 
context where nation-wide Covid-19 vaccination programs were now underway and the country was experiencing a third wave of infections after the Christmas period, remained as high as they ever have. In the 2019 November election VOX banked 15.1\% of votes cast and the party's polling average in March 2021 was equal to $17.6 \%$.

Understanding trends in aggregate level electoral support for the populist radical right party is important as it allows us to ascertain whether the party is gaining political ground visà-vis its competitors in the political marketplace. To understand whether VOX is likely to be a victim of Covid-19, however, we need to also consider how the party, and its leader, are viewed by their own supporters. Challenger parties' political longevity is often limited by their inability not only to gain new voters but also to ensure they retain the support that they gather during maidan successes (De Vries and Hobolt, 2020). In Figure 5, we visualize the relative approval rating of Abascal (VOX leader) vis-à-vis Casado (People's Party leader) among those individuals who reported to have voted for VOX in the November 2019 elections. The relative measure indicates to what extent VOX voters evaluate the populist radical right leader more positively than Casado: positive values indicate they are more supportive of Abascal, negative values indicate they are more supportive of Casado, and values of zero signal symmetrical evaluations for the two leaders. We would consider VOX's electoral longevity to be under threat in those situations where the party's own supporters provided an equal or more positive assessment of the mainstream right leader. 


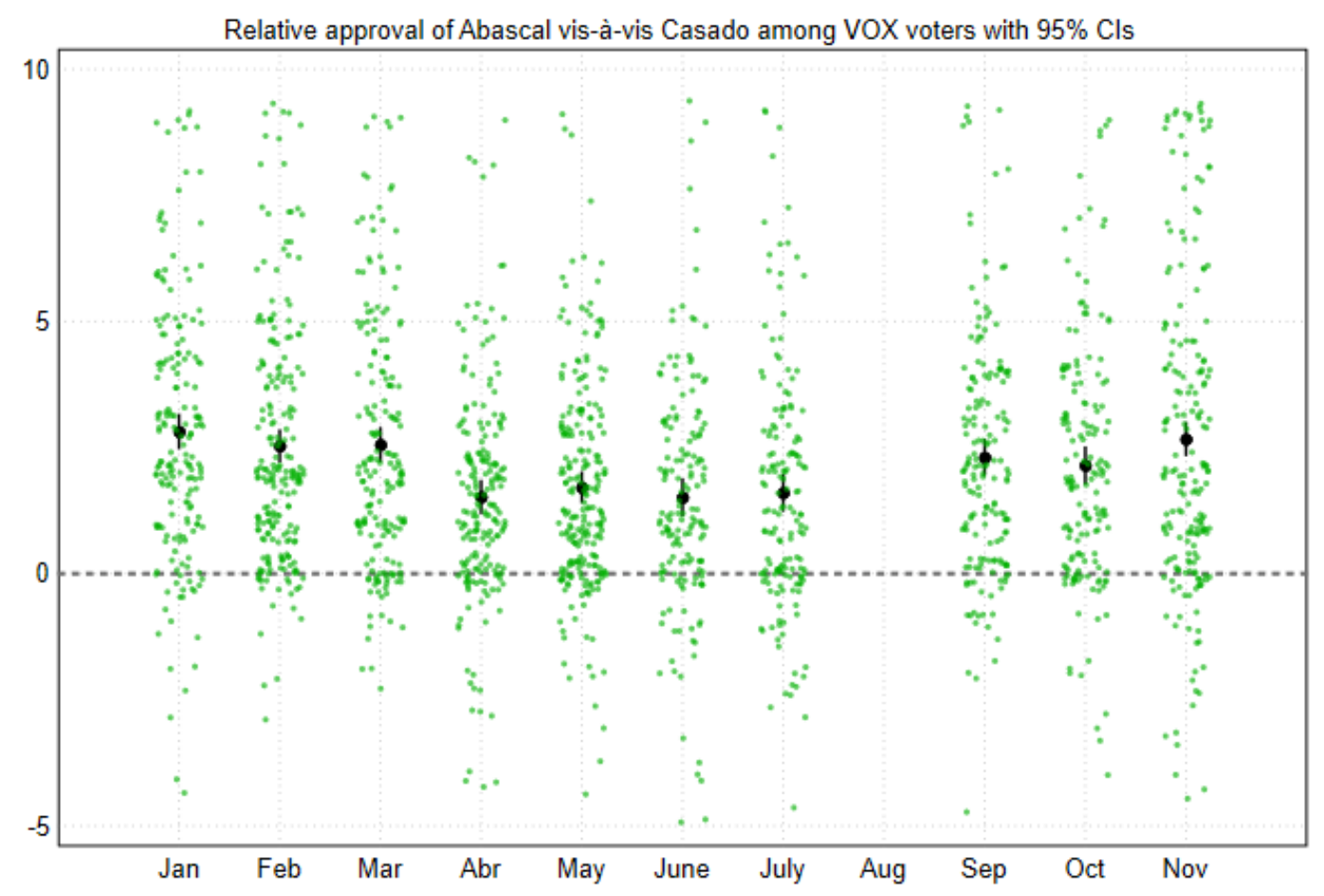

Figure 5: Relative support for VOX's leader among VOX voters

Source: Elaboration of the authors based on CIS monthly barometer data

Throughout the period of the pandemic and regardless of the three infection waves experienced in Spain, VOX's voters remained, on average, more inclined to favour Abascal over Casado. There was, however, a significant fall in the relative support of the former between the period of April and July. During this period, VOX supporters became significantly less likely the believe that Abascal was outperforming the mainstream right's lead candidate. This slump in the relative approval of the VOX leadership amongst their own supports mirrors the negative trends in support during the same period observed amongst the wider population. We observe, however, that in line with the aggregate polling trends data visualized above in Figure 3, there is also a swift return in the level of support for VOX's leader after August. Whilst we cannot identify a causal effect, it is worth highlighting that the bump in both the aggregate polling as well as in the relative support for the Abascal amongst VOX's voter base 
does coincide with the legislative maneuvering of the party in the form of the no confidence motion. Descriptively at least, it appears that adopting an aggressive and confrontational stance against the governing coalition, as well as the passive opposition exercised by the People's Party, provided potential dividends for the party. We can, therefore, interpret the strategic incentives behind VOX's legislative acts as a manifestation of the ongoing party competition dynamics taking place within the increasingly crowded right-wing space (Alonso and Field, 2021; Rama, Cordero and Zagorski, 2021).

\section{Conclusion}

Spain has been one of the countries most hit by the pandemic. Especially during the first wave, it was the country (together with Italy) with the worst indicators in terms of deaths and infection rates (Dombey, 2020a). In line with the goal of this special issue, this contribution aims to provide insight into the impact of the COVID-19 pandemic on a relatively new populist radical right party in Spain. Our analysis considers three empirical questions. First: how VOX discursively framed the pandemic. Second: how VOX as an opposition party, has responded to the. Third: how the pandemic affected the popularity of the populist radical right.

Looking at the party's framing of the COVID-19 crisis, in general terms, for VOX the pandemic was a matter of government (in)competence and an issue of freedom, going in hand the approach of other populist radical right-wing parties in opposition. Moreover, VOX leaders in different occasion referred to the "Chinese virus", blaming China for the pandemic and maintain, very much in line with Trumpian discourse, that "they [China] should pay for it"xviii as well as the EU' mismanagement of the vaccine rollout programme.

VOX's strategic reaction to the pandemic resulted in the party leadership organizing different protests against the government under claims of the "left-wing progressive dictatorship's" mismanagement of the ongoing crisis. The political climax of this aggressive 
opposition took the form of the party's no-confidence motion in the national legislature in which VOX defined Sanchez-ed PSOE-UP coalition government as "the worst in [Spain's] eighty years of history" and "the government that has dealt worse with the COVID-19 pandemic"xix. As we detail above, this no-hope parliamentary maneuver was a strategic act of political theatre that allowed the populist right-wing challenger to maximize political exposure and to dominate the public discourse in order to present itself as the primary and vocal government in waiting.

Third, looking at the effects of the pandemic on the popularity of VOX we observe that VOX voters seem to approve of the party's choices. The level of popular support enjoyed by the party shows, despite short-term dips, no long-term variation. Despite experiencing a small lull in support at the initial lockdown came into force, both support for the party and approval for the party's leader within VOX's support base has remained strong. The inability of the People's Party to reclaim more of its (traditional) support back behind the mainstream right, despite clear copy-cat tactics by some of party's regional leaders (e.g., Ayuso in Madrid) represents a dilemma for the party going forward.

The long-term trajectory of VOX appears secure. Despite punditry signaling Covid-19 as a potential threat to the populist radical right, we find no evidence that the virus has or is likely to threaten VOX's increasingly consolidated position as a strong and stable alternative to the mainstream right in the party system. If anything, we anticipate that the post Covid-19 trajectory of the party has the potential to provide fruitful gains for the challengers. Once the immediate health comes to its eventual end, the economic malaise engendered by year-long inhibitors of economic growth is likely to rear its head. Not only have economies retracted during the Covid-19 period but state governments, like Spain's have activated emergency furlough schemes and fit the bill for nation-wide vaccination programmes, both of which carry large fiscal price tags. If economic uncertainty is to become more of a constant of voters' minds, 
then VOX is likely to profit from the crisis since its anti-immigration stance will probably

resonate more with voters in times of economic trouble.

i For example, whilst some populist radical right-wing parties are inclusive of sexual minorities in their conceptualisation of the homogenous collective (Akkerman, 2005; Spierings, 2021; Spierings et al., 2015), others, including VOX (Rama et al., 2021), do not.

ii https://twitter.com/vox_es/status/1368306745492267018?s=20

https://twitter.com/vox_es/status/1352623830397837315

iii https://www.youtube.com/watch?v=eFXLFpVIBNQ

iv https://twitter.com/AgustinRosety/status/1353349771717652483

$\mathrm{v}$ https://www.elplural.com/politica/espana/vox-culpa-feministas-muertos-coronavirus-olvida-mitin-

$8 \mathrm{~m} \_236947102$

vi https://www.abc.es/espana/abci-ortega-smith-mostro-sintomas-coronavirus-vistalegre-

202003101346_video.html?ref=https:\%2F\%2Fwww.google.com\%2F

vii https://www.lavanguardia.com/politica/20200314/474130186160/embajada-china-ortega-smith-

racista-malditos-virus-chinos-coronavirus.html

viii https://www.youtube.com/watch? $v=$ cpqEm3qXm2I

ix Abascal defined the left-wing government as electorally fraudulent not in legal but rather political terms. First, they attacked the socialist government installed after the no confidence motion as a product of a coup d'etat. Once the progressive coalition between the Socialists and the hard-left (UP) was installed, VOX defined the government as fraudulent given Sánchez' multiple public statements where he promised not to form a coalition with UP.

x https://twitter.com/vox_es/status/1191515752974737408?s=20

xi https://www.youtube.com/watch? $\mathrm{v}=\mathrm{fDzRbn} 3 \mathrm{kXMc}$

xii https://www.heraldo.es/noticias/nacional/2021/07/14/el-tc-declara-inconstitucional-el-primer-

estado-de-alarma-decretado-por-la-covid-1506320.html?autoref=true

xiii https://twitter.com/vox_es/status/1350852209987235845?s=20

${ }^{\text {xiv }}$ Polarisation is measured, via CHES data, using Dalton (2008):

Polarization Index $x_{c, t}$

$$
=\sqrt{\sum_{i=1}^{n}\left(\frac{(\text { PartyCovidPosition }- \text { SystemCovidPosition })}{100}\right)^{2} * \text { VoteShare }_{i, t}}
$$

NB: As demonstrated in Figure A1 in the appendix, polarisation on the dominant left-right dimension does not necessarily predict polarisation on Covid-19 positions

${ }^{x v}$ In another example of the People's Party engaging in copy-cat tactics, the party's Trump-like regional president in Madrid, Isabel Diaz Ayuso, also flirted with the sourcing her own vaccines outside the EU-controlled programme. See: https://www.eldiario.es/madrid/ayuso-negocio-cuentacompra-vacuna-rusa-sputnik-febrero_1_7379425.html

xvi https://www.20minutos.es/noticia/4267930/0/espinosa-monteros-compara-manifestacion-voxcelebracion-mundial-futbol/?autoref=true

xvii https://twitter.com/TeoGarciaEgea/status/1288414209496297473?s=20

xviii https://www.elespanol.com/espana/politica/20201021/vox-declara-guerra-republica-popular-

china-expansion/529947521_0.html

xix https://www.youtube.com/watch? $=00$ YaCXj0ZLc

${ }^{\mathrm{xix}} \mathrm{https}$ //www.europapress.es/nacional/noticia-vox-no-apoya-obligatoriedad-vacuna-covid-

comprende-haya-personas-cierto-temor-20201117143715.html 


\section{References}

Akkerman T (2005) Anti-immigration parties and the defence of liberal values: The exceptional case of the List Pim Fortuyn. Journal of Political Ideologies 10(3): 337354.

Alonso S and Field BN (2021) Spain: The Development and Decline of the Popular Party in Bale T and Rovira Kaltwasser C (eds), Riding the Populist Wave: Europe's Mainstream Right in Crisis. Cambidge: Cambridge University Press.

Alonso S and Rovira Kaltwasser C (2015) Spain: No Country for the Populist Radical Right? South European Society and Politics 20(1): 21-45.

Baekgaard M, Christensen J, Madsen JK, et al. (2020) Rallying around the flag in times of COVID-19: Societal lockdown and trust in democratic institutions. Journal of Behavioral Public Administration 3(2).

Bernardez-Rodal A, Rey PR and Franco YG (2020) Radical right parties and anti-feminist speech on Instagram: Vox and the 2019 Spanish general election. Party Politics EarlyView. DOI: 10.1177/1354068820968839.

Betz HG and Meret S (2009) Revisiting Lepanto: The political mobilization against Islam in contemporary Western Europe. Patterns of Prejudice 43(3-4): 313-334.

Bol D, Giani M, Blais A, et al. (2021) The effect of COVID-19 lockdowns on political support: Some good news for democracy? European Journal of Political Research 60(2): 497-505.

Casado P (2020) Intervención - debate de la moción de censura.

Chowanietz C (2011) Rallying around the flag or railing against the government? political parties' reactions to terrorist acts. Party Politics 17(5): 673-698.

De Vries CE and Hobolt SB (2020) Political Entrepeneurs. The Rise of Challenger Parties in Europe. Princeton, New Jersey: Princeton University Press. 
Delis A, Matakos K and Xefteris D (2020) Electoral spillovers in an intertwined world: Brexit Effects on the 2016 Spanish Vote. British Journal of Political Science 50(3): $1169-1174$.

Devine D and Murphy J (2020) Does Media Coverage Drive Public Support for UKIP or Does Public Support for UKIP Drive Media Coverage? British Journal of Political Science 50(3): 893-910.

Dombey D (2020a) Covid: why Spain is hit worse than the rest of Europe. Financial Times, 10 September.

Dombey D (2020b) Political divisions deepen as Spain battles coronavirus. Financial Times, April.

English O (2020) Coronavirus' next victim: Populism. POLITICO, 18 March.

Field BN (2016) Why Minority Governments Work: Multilevel Territorial Politics in Spain. Basingstoke: Palgrave MacMillan.

Hargreaves Heap S, Koop C, Matakos K, et al. (2020) COVID-19 and people's health wealth preferences: information effects and policy implications. SSRN Electronic Journal. DOI: 10.2139/ssrn.3605003.

Jennings W, Stoker G, Willis H, et al. (2021) Lack of trust and social media echo chambers predict COVID-19 vaccine hesitancy. medRxiv EarlyView.

Louwerse T, Sieberer U, Tuttnauer O, et al. (2021) Opposition in times of crisis: COVID-19 in parliamentary debates. West European Politics EarlyView. DOI: 10.1080/01402382.2021.1886519.

Mendes MS and Dennison J (2021) Explaining the emergence of the radical right in Spain and Portugal: salience, stigma and supply. West European Politics 4(4): 752-775.

Minder R (2020) Spain Becomes Latest Epicenter of Coronavirus After a Faltering Response. The New York Times, March. 
Morgenstern S and Zechmeister E (2001) Better the devil you know than the saint you don't?

Risk propensity and vote choice in Mexico. Journal of Politics 63(1): 93-119.

Mudde C (2007) Populist Radical Right Parties in Europe. Cambridge: Cambridge

University Press.

Mudde C (2019) The Far-Right Today. Cambridge: Polity Press.

Negrete B (2021) Vox propone que España compre vacunas al margen de la UE pero no al ‘estilo Hungría’. Voz Populi, 26 February.

Neundorf A and Pardos-Prado S (2020) The Impact of Covid-19 on Trump's Electoral

Demise. SocArXiv Online. DOI: https://doi.org/10.31235/osf.io/cg3fm.

Norris P (2020) Measuring populism worldwide. Party Politics EarlyView. DOI:

$10.1177 / 1354068820927686$.

Olivas Osuna JJ and Rama J (2021) COVID-19: A Political Virus? VOX's Populist

Discourse in Times of Crisis. Frontiers in Political Science 3: 1-17. DOI:

10.3389/fpos.2021.678526.

Pérez Nievas S and Rama J (2018) Las bases sociales y actitudinales del nacionalismo:

Cataluña, Galicia y País Vasco. In: Blanco A, Chueca A, López-Ruiz JA, et al. (eds)

Informe España 2018. Madrid: Cátedra J.M. Martín Patino, pp. 301-364.

Rachman G (2020) Coronavirus could kill off populism. Financial Times, 29 June.

Rama, J, Cordero, G and Zagorski, P (2021) Three Is a Crowd? Podemos, Ciudadanos, and

VOX: The End of Bipartisanship in Spain. Frontiers in Political Science.

Rama J, Zanotti L, Turnbull-Dugarte SJ, et al. (2021) VOX: The Rise of Spanish Populist Radical Right. London: Routledge.

Ribera Payá P and Martínez JID (2020) The end of the Spanish exception: the far right in the Spanish Parliament. European Politics and Society EarlyView: 1-25.

Rooduijn M, Van Kessel S, Froio C, et al. (2019) The PopuList: An Overview of Populist, 
Far Right, Far Left and Eurosceptic Parties in Europe. Available at: www.popu-list.com. Sánchez-Cuenca I and Dinas E (2012) Introduction: Voters and Parties in the Spanish Political Space. South European Society and Politics 17(3): 365-374.

Simón P (2020) The Multiple Spanish Elections of April and May 2019: The Impact of Territorial and Left-right Polarisation. South European Society and Politics EarlyView. DOI: $10.1080 / 13608746.2020 .1756612$.

Spierings N (2021) Homonationalism and Voting for the Populist Radical Right: Addressing Unanswered Questions by Zooming in on the Dutch Case. International Journal of Public Opinion Research 33(1): 171-182.

Spierings N, Zaslove A, Mügge LM, et al. (2015) Gender and populist radical-right politics: An introduction. Patterns of Prejudice 49(1-2): 3-15.

Turnbull-Dugarte SJ (2019) Explaining the end of Spanish exceptionalism and electoral support for Vox. Research \& Politics 6(2): 1-8. DOI: 10.1177/2053168019851680. Turnbull-Dugarte SJ, Rama J and Santana A (2020) The Baskerville's dog suddenly started barking: voting for VOX in the 2019 Spanish general elections. Political Research Exchange 2(1). DOI: 10.1080/2474736X.2020.1781543.

Turnbull-Dugarte SJ and Devine D (2021) Can EU judicial intervention increase polity scepticism? Quasi-experimental evidence from Spain. Journal of European Public Policy EarlyView. DOI: 10.1080/13501763.2021.1901963.

Turnbull-Dugarte SJ and Rama J (2021) Madrid's regional election: How we got here, what happened, and why it matters. LSE EUROPP. https://blogs.lse.ac.uk/europpblog/2021/05/05/madrids-regional-election-how-we-gothere-what-happened-and-why-it-matters/

VOX (2019) 100 medidas para la España viva. Avaliable at https://www.voxespana.es/noticias/100-medidas-urgentes-vox-espana-20181006 
Wheeler D (2020) VOX in the age of Covid-19: The Populist Protest Turn in Spanish Politics. Journal of International Affairs 73(2): 173-184.

Wondreys J and Mudde C (2020) Victims of the Pandemic? European Far-Right Parties and COVID-19. Nationalities Papers. DOI: 10.1017/nps.2020.93. 
Appendix for: Surviving but not thriving: VOX and Spain in times of Covid-19

Table A 1: Model output for Figure 3

$\underline{\text { Party vote recall } \quad \operatorname{Pr} \text { (Willing to take the vaccine) }}$

Reference: PSOE

People's party

$0.07 * * *$

VOX

$(0.02)$

$-0.17 * * *$

$(0.04)$

Unidas Podemos

$0.05^{*}$

$(0.03)$

Ciudadanos

$-0.07 * *$

$(0.03)$

Other

$-0.09 * * *$

Abstained

$(0.03)$

Temporal trends

$-0.08 * * *$

$(0.03)$

$-0.05 * * *$

$(0.01)$

Constant

$0.55 * * *$

$(0.02)$

Observations $\quad 4,759$

R-squared 0.03

NB: Barometers employed: \#3292 (September); \#3296 (October); \#3300 (November)

Robust standard errors (clustered by survey wave) in parentheses

$$
* * * \mathrm{p}<0.01, * * \mathrm{p}<0.05, * \mathrm{p}<0.1
$$


Table A 2: Model output for Figure 2

Party vote recall

$\operatorname{Pr}$ (View lockdown measures as unnecessary)

Reference: PSOE

People's party

$-0.07 * * *$

$(0.01)$

VOX

$0.07 * * *$

$(0.02)$

Unidas Podemos

$-0.08 * * *$

$(0.01)$

Ciudadanos

$-0.03 * *$

Other

$(0.01)$

$-0.05 * * *$

$(0.01)$

Abstained

$-0.01$

$(0.01)$

Temporal trends

$0.06 * * *$

Constant

$(0.01)$

$0.08 * * *$

$(0.01)$

Observations

7,755

R-squared 0.03

NB: Barometers employed: \#3281 (May); \#3283 (June)

Robust standard errors (clustered by survey wave) in parentheses $* * * \mathrm{p}<0.01, * * \mathrm{p}<0.05, * \mathrm{p}<0.1$ 
Party system polarisation

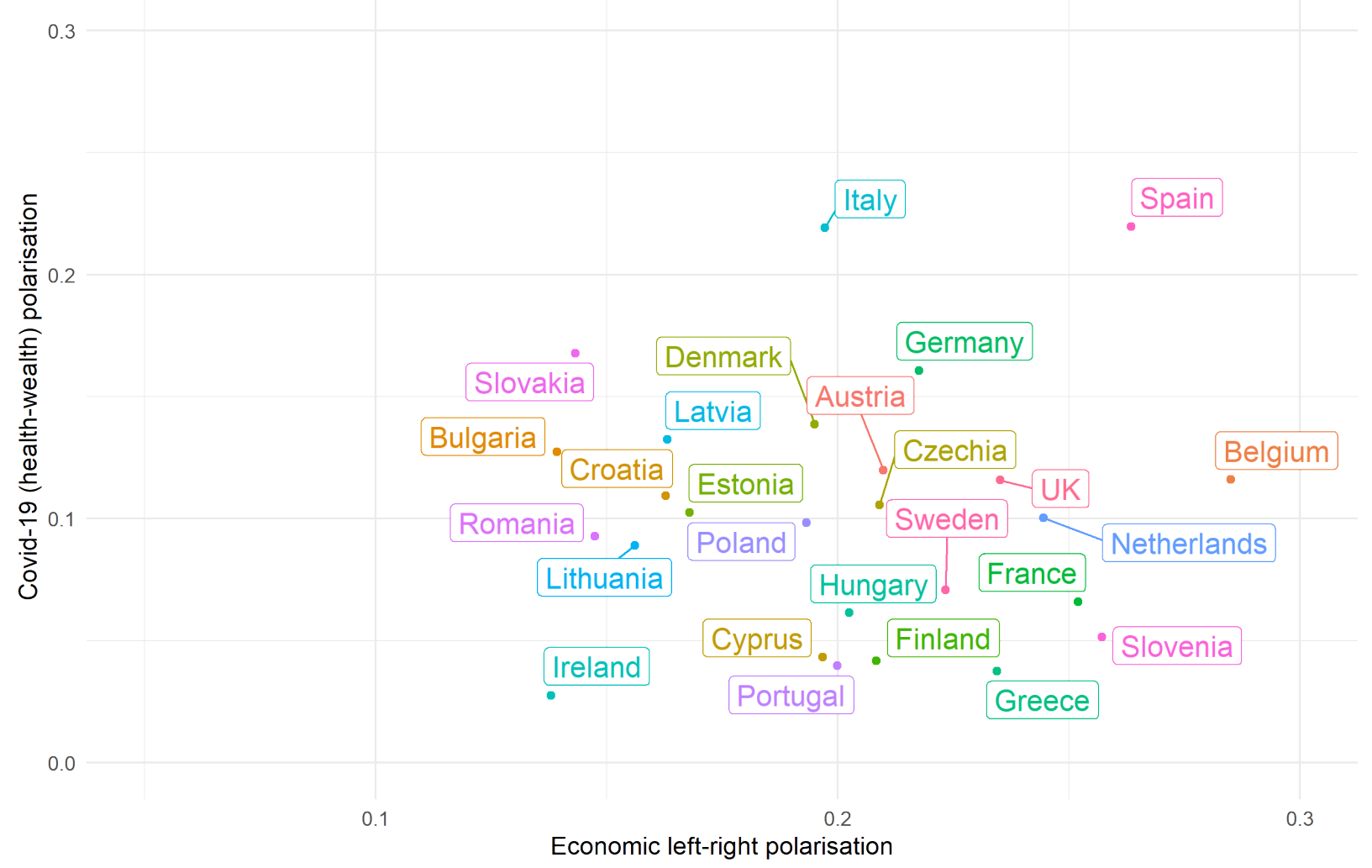

Figure A 1: Party system polarisation compared. 